\title{
Environmental Sanitation Practices: A Case Study of Solid Waste Management in Semi-Urban Communities in Orlu, Imo State Nigeria
}

\author{
Chukwuma B. Duru1, Anthony C. Iwu ${ }^{2 *}$, Kevin C. Diwe', Kenechi A. Uwakwe', Irene A. Merenu', \\ Ugochukwu C Madubueze ${ }^{3}$, Ijeoma N. Okedo-Alex ${ }^{3}$, Emmanuel U. Ndukwu², Ikechi Ohale², \\ Ernest Nwaigbo ${ }^{2}$
}

${ }^{1}$ Department of Community Medicine, Imo State University, Owerri, Nigeria

${ }^{2}$ Department of Community Medicine, Imo State University Teaching Hospital, Orlu, Nigeria

${ }^{3}$ Department of Community Medicine, Federal Teaching Hospital, Abakaliki, Nigeria

Email: iwuchinedu@yahoo.com,duruchukwuma16@yahoo.com

How to cite this paper: Duru, C.B., Iwu, A.C., Diwe, K.C., Uwakwe, K.A., Merenu, I.A., Madubueze, U.C., Okedo-Alex, I.N., Ndukwu, E.U., Ohale, I. and Nwaigbo, E. (2017) Environmental Sanitation Practices: A Case Study of Solid Waste Management in Semi-Urban Communities in Orlu, Imo State Nigeria. Occupational Diseases and Environmental Medicine, 5, 88-105. https://doi.org/10.4236/odem.2017.54009

Received: September 27, 2017 Accepted: October 31, 2017 Published: November 3, 2017

Copyright $\odot 2017$ by authors and Scientific Research Publishing Inc. This work is licensed under the Creative Commons Attribution International License (CC BY 4.0).

http://creativecommons.org/licenses/by/4.0/

\begin{abstract}
Background: Environmental sanitation is a fundamental process that is a key public health intervention which is essential for social, economic and overall health development of communities. Objective: To determine Knowledge, Attitude and Practices of Environmental Sanitation in Semi-Urban Communities in Orlu, Imo State, Nigeria. Methods: A cross sectional descriptive design using a multistage random sampling technique to select 426 participants from households and business premises in semi-urban communities in Orlu Local Government Area of Imo State. Data was collected using a pretested, semi structured, interviewer administered questionnaire. Descriptive analyses were done with frequencies and summary statistics to assess the respondents' knowledge, attitude and practices of environmental sanitation. Results: The results revealed that the mean age of the respondents' was $37.0 \pm 2.2$ with a male to female ratio of 1:1.2. Despite high awareness about environmental sanitation (95.0\%) reported among the respondents, proportion of them with good knowledge about environmental sanitation (22.9\%), attitude (38.6\%) and practice $(20.8 \%)$ towards environmental sanitation was low. The mean quantity of waste generated per week per household or business premise was $14.1 \pm 0.94 \mathrm{~kg}$ with a majority of the respondents $(80.0 \%)$, not separating their waste before disposal. The commonest solid waste component generated was organic/perishable materials (74.8\%) and the commonest disposal practice reported was open dumping (49.8\%). Conclusion: A lot of attention is still
\end{abstract}


required in the development of basic sanitation infrastructure and also, in the promotion of strategies or interventions that influence behavioural change towards environmental sanitation especially in developing countries like Nigeria.

\section{Keywords}

Knowledge, Attitude, Practice, Environmental Sanitation,

Sold Waste Management, Nigeria

\section{Introduction}

Environmental sanitation is a set of actions or a fundamental process of collecting and safely disposing all kinds of waste within the environment with the intention of protecting and promoting the individual health and quality of life of communities. Environmental sanitation generally includes the provision of facilities and services for the safe disposal of waste, the maintenance of hygienic conditions and the prevention of diseases [1]. So it is a key public health intervention that is essential for social and economic development especially in developing countries. This leads to the improvement of health, well-being and economic productivity and benefits the individual, household and community through the provision and practice of adequate sanitation, good hygiene and the use of safe water [2] [3].

In 2012, a study conducted by World Health Organization reported that, there was a return of 5.5 USD with respect to lower health costs, more productivity and fewer premature deaths for every 1 USD invested in sanitation [4]. Though, since 1990, there has been an improvement in sanitation with the proportion of people having access increasing from $54 \%$ to $68 \%$, the Millennium Development Goal target by 2015 was not achieved, as up to 700 million people remaining to attain the target, were still without adequate sanitation [4].

About $10 \%$ of the global burden of disease and one third of all annual deaths in low- and middle-income countries resulting from inadequate water, sanitation, and hygiene is believed to be due to poor sanitation [3] [4]. Furthermore, a correlation has also been observed between poverty, child infancy and diseases that are associated with poor sanitation; hence, especially in developing countries with inadequate sanitation which poses a significant public health risk, children in particular are most vulnerable to ill health [5]. Therefore, interventions targeted at sanitation improvements can significantly enhance health and wellbeing of the population by preventing, reducing the severity and impact of diseases associated with poor sanitation [6].

A key culprit of poor sanitation is diarrhoeal disease which is a significant group of feco-oral diseases that has substantial impact on the mortality patterns in children especially under the age of 3 years. Consequently, a study in Brazil also concluded that, introducing interventions geared towards improving sanita- 
tion and household living conditions will significantly decrease the incidence of diarrhoeal diseases and its' impact on health especially in children [7]. Poor sanitation has also been linked to acute respiratory infections [8], malnutrition [9] and in particular, neglected tropical diseases such as trachoma, soil-transmitted helminthiases and schistosomiasis; as many of these diseases can be transmitted feco-orally [3] [10].

In developing countries, majority of people in the rural communities lack sanitation and even with urbanization, the provision of improved sanitation remains a continuous challenge due to the inability to cope with the associated increase in population as communities move from rural, semi urban to urban development [3]. Also according to Daramola [11], the population growth in Nigerian cities is not accompanied by a corresponding increase in the provision of environmental sanitation facilities. So in addressing these challenges of sanitation in the semi urban and urban communities, the provision of sanitation infrastructure serves only as a means to an end, as the attitude and behaviour of the individuals, households and community as a whole, determines the end [12].

Now, the trend in the promotion of sanitation is progressively moving from the emphasis on centrally planned sanitation infrastructure to a demand led approach that empowers people to change behaviour and improve their own sanitation [3]. In this regard, simple health interventions such as hygiene and sanitation promotion in the prevention of diarrhoea have been central to the demand led approaches such as sanitation marketing, community led total sanitation and community health clubs; which begins with, and it is based on influencing peoples' attitude, what they know, do and want [13]. These interventions have also been successful and cost effective globally with respect to the cost of averting occurrences of morbidity and mortality [14].

Hence, the foundation for a successful demand led approach will be achieved mainly through strategies that improve knowledge, attitude and motivate the practice of safe sanitation by the individual; which is an important and effective approach in attaining better and sustainable sanitation within the households and communities. So this study sets out to determine the knowledge, attitude and practices of environmental sanitation in semi-urban communities with a view to designing specific strategies that targets behavioural change by improving their knowledge and attitude towards sanitation.

\section{Methodology}

\subsection{Study Area}

The study was conducted within semi-urban communities in Orlu Local Government Area (LGA) which is one of the twenty seven LGAs of Imo State in the South Eastern zone of Nigeria. Orlu LGA which is made up of 10 autonomous communities, is predominantly a semi-urban area covering $133 \mathrm{sq} \mathrm{km}$ with an estimated population of 142,792 and a population density of about 1074 persons per square kilometre according to the 2006 national census [15]. 


\subsection{Study Population/Study Design/Selection Criteria}

The study population comprised households and business premises within the semi-urban communities in Orlu LGA. The study was a descriptive cross sectional type. The criteria for selection was any individual aged 20 years and above from a household or business premise within the selected communities and had lived in the study area for at least one year. The selected individual was subsequently enrolled after informed consents were given. Any individual selected, that was unable to participate due to health issues was excluded.

\subsection{Sample Size Estimation}

The minimum sample size was calculated using the Cochrane formula [16]

$$
\mathrm{n}=\frac{\mathrm{Z}^{2} \mathrm{pq}}{\mathrm{d}^{2}}
$$

When $\mathrm{n}=$ minimum sample size, $\mathrm{Z}=$ Standard normal deviate corresponding to $5 \%$ significance level, $\mathrm{p}=$ proportion of the target population that had a moderate to good standard of practice relating to environmental sanitation (49\%) [17], $\mathrm{q}=1-\mathrm{p}(1-0.49=0.51), \mathrm{d}=$ tolerable error of margin set at $0.05, \mathrm{Z}=1.96$. Applying the formula above, and adjusting for incomplete and non-response rate, a sample size of 426 participants were studied.

\subsection{Sampling Technique}

The sampling technique used to select the participants for this study was the multistage random sampling technique. The first stage involved the selection of the communities that were studied. This was done using simple random sampling by balloting of which 3 semi-urban communities were selected from a list of 6 semi-urban autonomous communities that are part of the 10 communities (rural and semi-urban) that make up Orlu LGA. The second stage involved using simple random sampling by balloting to select two enumeration areas from each of the 3 selected semi-urban autonomous communities based on the Nigerian 2006 census enumeration area delineation. The third stage involved the selection of one participant from the individual household or business premise within the selected enumeration areas in the respective communities.

In each enumeration area within a particular community, a prominent location was identified and moving in a particular direction, each consecutive household or business premise was enrolled until 71 households and or business premises were selected. A total of 426 households and business premises were selected from the six enumeration areas within the respective communities. If there were more than one individual aged 20 years and above present in any household or business premise, balloting was done to select and enrol one eligible individual after an informed consent. Any household or business premise without an eligible individual present after two repeat visits or had only one adult individual present, who had not lived in the area for at least one year was 
skipped.

\subsection{Data Collection and Analysis}

Data was collected within a two month period from February to March 2016 using a pretested, semi structured, interviewer administered questionnaire. The questionnaire was developed by the researchers and pretested in another community in the LGA not selected for the study. The content validity was established qualitatively assessing each question against the intended construct. The questionnaire comprised 4 sections; section one: the socio-demographic and household characteristics; section two: the awareness and knowledge of environmental sanitation; section three: attitude towards environmental sanitation and section four: environmental sanitation practices and self-assessment of community sanitation.

The level of knowledge and practice of environmental sanitation was determined by scoring the questions that assessed knowledge or practice. For a single response question, an appropriate answer was scored 2; an inappropriate answer was scored 0 . For a multiple response question, up to 2 appropriate answers was scored 1; from 3 to 5 appropriate answers was scored 3 and greater than 5 appropriate answers was scored 5. In assessing the level of attitude towards environmental sanitation, a Likert scale was used. For a positive question, a response from strongly agree to strongly disagree, a score from 5 to 1 was allocated accordingly and for a negative question, a response of "strongly disagree" to "strongly agree", a score from 5 to 1 was allocated accordingly. The aggregate scores for each respondent according to the level of knowledge, attitude and practice of environmental sanitation were translated to a percentage and assessed against a scale of less than $60 \%$ for poor, $60 \%-80 \%$ for moderate and greater than $80 \%$ for good. For the self-assessment of community sanitation, each respondent was asked to rate the level of environmental sanitation in their respective communities as good, moderate or poor.

Data was cleaned and validated manually, then using Software Package for Social Sciences (IBM-SPSS) version 22, descriptive statistics (frequency tables and summary indices) were generated to assess the respondents' knowledge, attitude and practices of environmental sanitation.

\subsection{Ethical Considerations}

Ethical approval was obtained from the Ethics Committee of Imo State University Teaching Hospital Orlu. Informed consents were obtained from the participants. All authors hereby declare that the study was performed in accordance with the ethical standards laid down in the 1964 Declaration of Helsinki.

\section{Results}

Four hundred and twenty six copies of the questionnaire were administered but 420 copies were completely and correctly filled with a response rate of $98.6 \%$. 


\subsection{Socio-Demographic and Household Characteristics of Respondents in Semi-Urban Communities in Orlu LGA}

The mean age of the respondents was $37.0 \pm 2.2$ years with most of them being of Igbo extraction (93.6\%). Majority of the respondents were females (55.2\%), married or separated $(58.8 \%)$, having either no education or a primary level of education $(51.9 \%)$ and half of the respondents were of the Christian catholic faith $(50.0 \%)$. Majority of the respondents were living in either a one, two or three bedroom flat $(60.0 \%)$ with 6 or more household occupants $(59.5 \%)$ and having a borehole as their main source of water supply (55.7\%). A sizable proportion of the households (35.5\%) practice open defecation (Table 1).

\subsection{Awareness and Knowledge of Environmental Sanitation among Respondents in Semi-Urban Communities in Orlu LGA}

Most of respondents were aware about environmental sanitation (95.0\%) and majority of them, got their information about sanitation from the mass media such as the television (59.1\%) and the radio (56.6\%); and next, from community meetings $(41.4 \%)$. While a majority of the respondents $(73.7 \%)$ indicated that the objective of environmental sanitation was to promote health, close to $10 \%$ indicated that it was to avoid contact with people. Also, while a majority of the respondents indicated that waste disposal (83.7\%) and hand washing $(74.2 \%)$ constitutes appropriate environmental sanitation, less than half indicated that sewage disposal $(46.4 \%)$ and the provision of safe water $(35.8 \%)$ constitutes appropriate environmental sanitation. Similarly, while a majority of respondents regarded open dumping as an appropriate waste disposal method (68.9\%), only less than half regarded sanitary land fill (41.3\%) and incineration (37.4\%) as appropriate methods. Though, infection was reported as a result of inappropriate sanitation practices by a majority of the respondents $(72.7 \%)$, providing a place for criminal hideouts was also reported by as high as $21 \%$ of the respondents (Table 2).

Generally, a majority of the respondents (60.0\%) had an overall moderate level of knowledge about environmental sanitation with only less than one quarter (22.9\%) having an overall good level of knowledge (Figure 1).

\subsection{Attitude towards Environmental Sanitation among Respondents in Semi-Urban Communities in Orlu LGA}

A majority of the respondents either agreed or strongly agreed that surfaces and floors should be washed with clean water regularly $(77.6 \%)$, that it is necessary to dig pit toilets at a distance away from wells (69.0\%), that factories should be located outside the populated communities (65.0\%), that solid waste should be disposed daily $(61.2 \%)$, that all communities should have a day for general clean-up $(85.0 \%)$ and that community sanitation should be taught in schools $(80.2 \%)$. As high as $17 \%-30 \%$ of the respondents were either undecided, agreed or strongly agreed that solid waste could be thrown into the stream $(21.4 \%)$, that 
Table 1. Socio-demographic and household characteristics of respondents in semi-urban communities in Orlu.

\begin{tabular}{|c|c|c|}
\hline Variable & Category & $\begin{array}{c}\text { Frequency (\%) } \\
\quad \mathrm{n}=420\end{array}$ \\
\hline Age (years) & $20-30$ & $105(25.0)$ \\
\hline \multirow[t]{2}{*}{ Mean age $(37.0 \pm 2.2)$} & $31-40$ & $126(30.0)$ \\
\hline & $>40$ & $189(45.0)$ \\
\hline \multirow[t]{2}{*}{ Gender } & Female & $232(55.2)$ \\
\hline & Male & $188(44.8)$ \\
\hline \multirow[t]{2}{*}{ Tribe } & Igbo & $393(93.6)$ \\
\hline & Non-Igbo & $27(6.4)$ \\
\hline \multirow[t]{4}{*}{ Religion } & Catholic & $210(50.0)$ \\
\hline & Pentecostal & $147(35.0)$ \\
\hline & Orthodox & $57(13.5)$ \\
\hline & Others & $6(1.5)$ \\
\hline \multirow[t]{3}{*}{ Marital status } & Married & $209(49.8)$ \\
\hline & Single & $173(41.2)$ \\
\hline & Separated & $38(9.0)$ \\
\hline \multirow[t]{4}{*}{ Educational level } & Tertiary & $159(37.9)$ \\
\hline & Secondary & $43(10.2)$ \\
\hline & Primary & $201(47.9)$ \\
\hline & None & $17(4.0)$ \\
\hline \multirow[t]{5}{*}{ Type of House } & Duplex & $61(14.5)$ \\
\hline & Bungalow & $107(25.5)$ \\
\hline & 3 bed room flat & $103(24.5)$ \\
\hline & 2 bed room flat & $84(20.0)$ \\
\hline & 1 bed room flat & $65(15.5)$ \\
\hline \multirow[t]{5}{*}{ Household size } & $1-5$ & $170(40.5)$ \\
\hline & $6-10$ & $145(34.5)$ \\
\hline & $>10$ & $105(25.0)$ \\
\hline & Borehole & $234(55.7)$ \\
\hline & Stream and rivers & $105(25.0)$ \\
\hline \multirow[t]{3}{*}{ Main source of water } & Tanker supply & $41(9.8)$ \\
\hline & Public supply & $22(5.2)$ \\
\hline & Rain water & $18(4.3)$ \\
\hline \multirow[t]{3}{*}{ Toilet facilities } & Water closet & $252(60.0)$ \\
\hline & Open defecation & $149(35.5)$ \\
\hline & Pit toilet & $19(4.5)$ \\
\hline
\end{tabular}

urination and defecation could be done near wells (17.1\%), that sewage could be discharged into the stream (30.0\%) and that solid waste could be spread around the compound to decay naturally (30.0\%). A majority of the respondents were undecided, disagreed or strongly disagreed that all waste bins should have covers (55.0\%). Also a majority of the respondents were undecided, agreed or strongly agreed that open waste bins could be kept in the kitchen (60.0\%) and that it is unnecessary to separate waste before disposal (80.0\%) (Table 3). 
Table 2. Awareness and knowledge of environmental sanitation among respondents insemi-urban communities in Orlu.

\begin{tabular}{|c|c|c|}
\hline Variable & Category & Frequency (\%) \\
\hline $\begin{array}{l}\text { Have you heard about environmental } \\
\text { sanitation } \\
(\mathrm{n}=420)\end{array}$ & $\begin{array}{l}\text { Yes } \\
\text { No }\end{array}$ & $\begin{array}{c}399(95.0) \\
21(5.0)\end{array}$ \\
\hline $\begin{array}{l}\text { *Sources of information } \\
(\mathrm{n}=399)\end{array}$ & $\begin{array}{l}\text { Television } \\
\text { Radio } \\
\text { Community meetings } \\
\text { Health personnel } \\
\text { Market } \\
\text { Newspaper } \\
\text { Neighbours } \\
\text { Friends/relatives } \\
\text { Poster/sign boards } \\
\text { internet } \\
\text { Sanitation agencies }\end{array}$ & $\begin{array}{l}236(59.1) \\
226(56.6) \\
165(41.4) \\
129(32.3) \\
109(27.3) \\
101(25.3) \\
91(22.8) \\
77(19.3) \\
62(15.5) \\
43(10.8) \\
20(5.0)\end{array}$ \\
\hline $\begin{array}{l}{ }^{*} \text { What is the objective of } \\
\text { Environmental Sanitation? } \\
(\mathrm{n}=399)\end{array}$ & $\begin{array}{l}\text { Promoting health } \\
\text { Preventing diseases } \\
\text { Personal cleanliness } \\
\text { Avoid contact with people }\end{array}$ & $\begin{array}{c}294(73.7) \\
189(47.4) \\
46(11.5) \\
38(9.5)\end{array}$ \\
\hline $\begin{array}{l}{ }^{*} \text { What constitutes appropriate } \\
\text { Environmental Sanitation? } \\
(\mathrm{n}=399)\end{array}$ & $\begin{array}{l}\text { Waste disposal } \\
\text { Hand washing } \\
\text { Safe guarding food } \\
\text { Sewage disposal } \\
\text { Provision of safe water } \\
\text { Provision of good housing }\end{array}$ & $\begin{array}{l}334(83.7) \\
296(74.2) \\
256(64.2) \\
185(46.4) \\
143(35.8) \\
25(6.3)\end{array}$ \\
\hline $\begin{array}{l}\text { *Types of appropriate waste disposal } \\
\text { methods known }(\mathrm{n}=334)\end{array}$ & $\begin{array}{l}\text { Open dumping } \\
\text { Sanitary land fill } \\
\text { Incineration/burning } \\
\text { Recycling } \\
\text { Hog feeding } \\
\text { Composting }\end{array}$ & $\begin{array}{l}230(68.9) \\
138(41.3) \\
125(37.4) \\
99(29.6) \\
68(20.4) \\
62(18.6)\end{array}$ \\
\hline $\begin{array}{l}{ }^{*} \text { Consequences of inappropriate } \\
\text { sanitation practices } \\
(\mathrm{n}=399)\end{array}$ & $\begin{array}{l}\text { Causes infection } \\
\text { Unhealthy living conditions } \\
\text { Blocks drainages } \\
\text { Pollutes water bodies } \\
\text { Provides breeding sites } \\
\text { Causes injuries } \\
\text { Provides criminal hideouts }\end{array}$ & $\begin{array}{l}290(72.7) \\
277(69.4) \\
269(67.4) \\
254(63.7) \\
229(57.4) \\
228(57.1) \\
83(20.8)\end{array}$ \\
\hline
\end{tabular}

Generally, a majority of the respondents (55.4\%) had an overall moderate level of positive attitude towards environmental sanitation with only above one third having an overall good level of positive attitude (38.6\%) (Figure 2).

\subsection{Environmental Sanitation Practices among Respondents in Semi-Urban Communities in Orlu LGA}

About three quarters of the respondents mainly generate, organic and perishable solid waste (74.8\%) and a majority of the respondents generate $5-20 \mathrm{~kg}$ of solid 


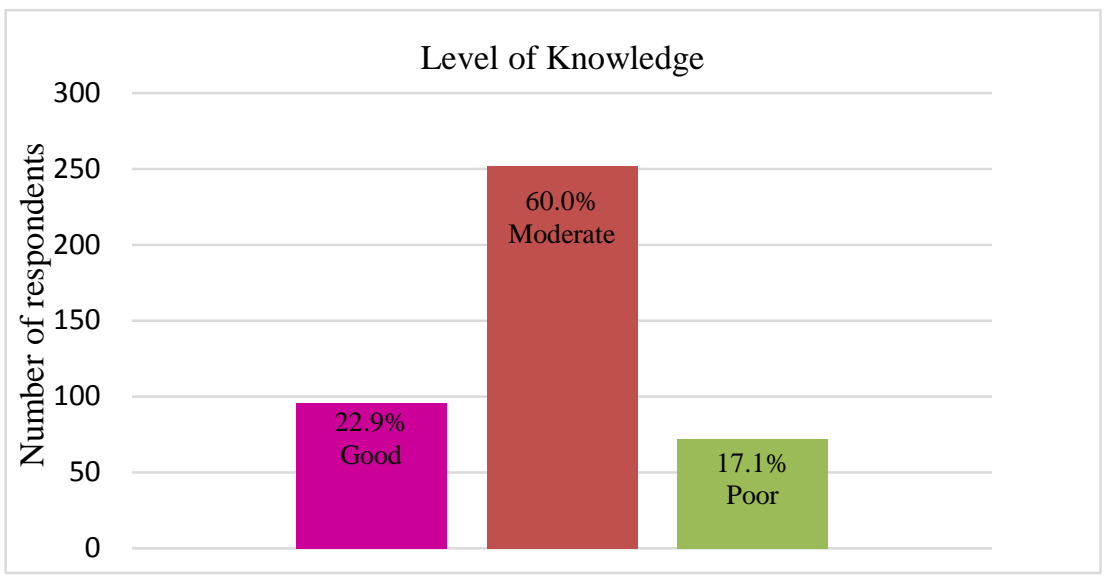

Figure 1. Overall level of knowledge of Sanitation among respondents in semi-urban Communities in Orlu.

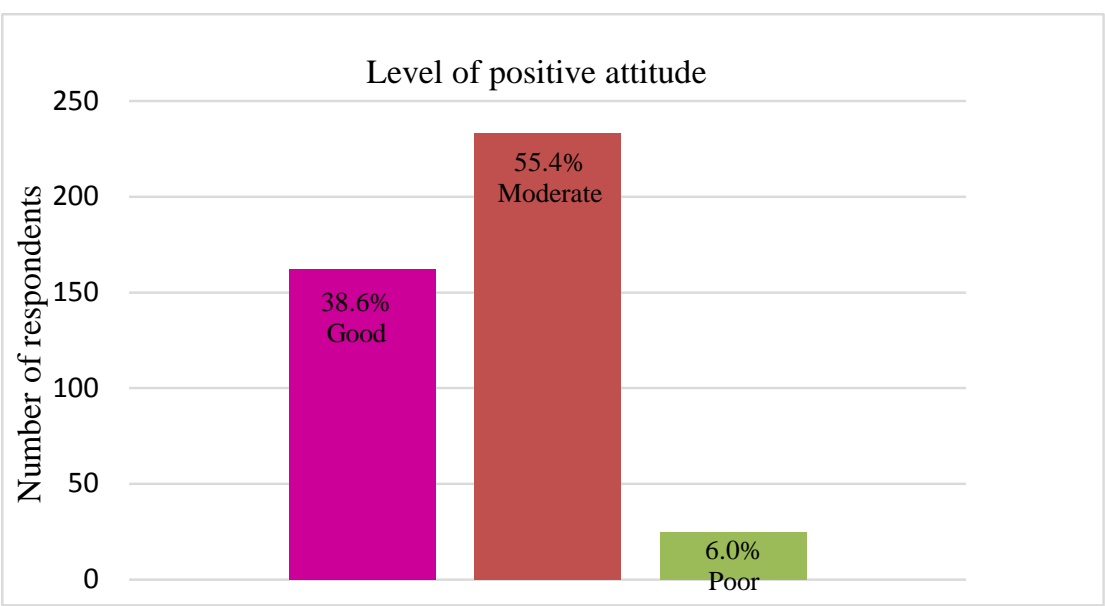

Figure 2. Overall level of positive attitude towards Sanitation among respondents in semi-urban communities in Orlu.

waste per household or business premise per week (71.4\%) with an average waste generated per person per week of $2.69 \mathrm{~kg}$. Even though a majority of the respondents store their waste using covered bins (55.0\%), as high as $22 \%-30 \%$ of the respondents still store their waste either by dumping openly $(30.2 \%)$ or by using uncovered bins $(27.6 \%)$ or baskets $(22.6 \%)$ with close to half of the respondents disposing their waste 2 - 3 times per week (48.1\%). A majority of the respondents use wheel barrows and head pans (73.8\%) to transport their waste to the dump site and do not pay any form of dues for waste disposal (80.2\%). A majority of the respondents either reported that the community did not have a designated central area for waste disposal or did not know of its existence in the community (65.3\%) and commonest form of waste disposal practiced by household was open dumping, (49.8\%). A majority of the respondents reported not having public toilets in their communities $(59.8 \%)$ but close to half of the respondents reported having a health committee (50.7\%). A majority of the respondents reported either not being visited by sanitary inspectors or not knowing 
Table 3. Attitude towards environmental sanitation among respondents in Semi-urban communities in Orlu.

\begin{tabular}{|c|c|c|}
\hline Variable & Category & $\begin{array}{l}\text { Frequency (\%) } \\
\quad(n=420)\end{array}$ \\
\hline \multirow{5}{*}{$\begin{array}{l}\text { Surfaces and floors should be washed with } \\
\text { clean water regularly? }\end{array}$} & Strongly Agree & $210(50.0)$ \\
\hline & Agree & $116(27.6)$ \\
\hline & Undecided & $79(18.8)$ \\
\hline & Disagree & $10(2.4)$ \\
\hline & Strongly disagree & $5(1.2)$ \\
\hline \multirow[t]{5}{*}{ Solid waste could be thrown into the stream } & Strongly Agree & $6(1.4)$ \\
\hline & Agree & $62(14.8)$ \\
\hline & Undecided & $22(5.2)$ \\
\hline & Disagree & $160(38.1)$ \\
\hline & Strongly disagree & $170(40.5)$ \\
\hline \multirow[t]{5}{*}{ Urination and defecation could be done near wells } & Strongly Agree & $5(1.2)$ \\
\hline & Agree & $8(1.9)$ \\
\hline & Undecided & $59(14.0)$ \\
\hline & Disagree & $188(44.8)$ \\
\hline & Strongly disagree & $160(38.1)$ \\
\hline \multirow[t]{5}{*}{ Sewage could be discharged into the stream } & Strongly Agree & $3(0.7)$ \\
\hline & Agree & $60(14.3)$ \\
\hline & Undecided & $63(15.0)$ \\
\hline & Disagree & $105(25.0)$ \\
\hline & Strongly disagree & $189(45.0)$ \\
\hline \multirow{5}{*}{$\begin{array}{l}\text { It is necessary to dig pit toilets at a distance away } \\
\text { from wells }\end{array}$} & Strongly Agree & $126(30.0)$ \\
\hline & Agree & $164(39.0)$ \\
\hline & Undecided & $25(6.0)$ \\
\hline & Disagree & $63(15.0)$ \\
\hline & Strongly disagree & $42(10.0)$ \\
\hline \multirow{5}{*}{$\begin{array}{l}\text { Factories should be located outside the } \\
\text { populated communities }\end{array}$} & Strongly Agree & $83(19.8)$ \\
\hline & Agree & $190(45.2)$ \\
\hline & Undecided & $61(14.5)$ \\
\hline & Disagree & $62(14.8)$ \\
\hline & Strongly disagree & $24(5.7)$ \\
\hline \multirow[t]{5}{*}{ Solid waste should be disposed daily } & Strongly Agree & $40(9.5)$ \\
\hline & Agree & $217(51.7)$ \\
\hline & Undecided & $150(35.7)$ \\
\hline & Disagree & $4(1.0)$ \\
\hline & Strongly disagree & $9(2.1)$ \\
\hline \multirow{5}{*}{$\begin{array}{l}\text { Solid waste could be spread around the } \\
\text { compound to decay naturally }\end{array}$} & Strongly Agree & $0(0.0)$ \\
\hline & Agree & $21(5.0)$ \\
\hline & Undecided & $105(25.0)$ \\
\hline & Disagree & $63(15.0)$ \\
\hline & Strongly disagree & $231(55.0)$ \\
\hline \multirow[t]{5}{*}{ All waste bins should have covers } & Strongly Agree & $129(30.7)$ \\
\hline & Agree & $60(14.3)$ \\
\hline & Undecided & $162(38.6)$ \\
\hline & Disagree & $48(11.4)$ \\
\hline & Strongly disagree & $21(5.0)$ \\
\hline
\end{tabular}




\section{Continued}

\begin{tabular}{lcc}
\hline All communities should have a day for & Strongly Agree & $189(45.0)$ \\
general clean up & Agree & $168(40.0)$ \\
& Undecided & $26(6.2)$ \\
& Disagree & $21(5.0)$ \\
& Strongly disagree & $16(3.8)$ \\
Open waste bins could be kept in the kitchen & Strongly Agree & $42(10.0)$ \\
& Agree & $105(25.0)$ \\
& Undecided & $105(25.0)$ \\
It is not necessary to separate waste before disposal & Disagree & $84(20.0)$ \\
& Strongly disagree & $84(20.0)$ \\
& Strongly Agree & $42(10.0)$ \\
& Agree & $42(10.0)$ \\
& Undecided & $252(60.0)$ \\
& Disagree & $40(9.5)$ \\
Community sanitation should be taught in school & Strongly disagree & $44(10.5)$ \\
& & \\
& Strongly Agree & $126(30.0)$ \\
& Agree & $211(50.2)$ \\
& Undecided & $81(19.3)$ \\
& Disagree & $2(0.5)$ \\
& Strongly disagree & $0(0.0)$ \\
\hline
\end{tabular}

at all, if they visited their communities (80.4\%). Of those that reported being visited by sanitary inspectors, a majority reported that the frequency of visits were either monthly or yearly (78.0\%). Similarly, a majority of the respondents reported that their communities observe a monthly environmental sanitation day (70.2\%) but close to half of the respondents (49.5\%) either reported that, it was of no benefit or did not know if observing the environmental sanitation day benefited the community. Close to $45 \%$ of the respondents reported having communal bush clearing and gutter cleaning activities, of which, a majority (78.1\%) reported having the communal activities every month (Table 4). Furthermore, though a majority of the respondents (52.9\%) had an overall poor level of environmental sanitation practice, most of the respondents (87.2\%) rated their level of community sanitation as moderate to good (Figure 3 and Figure 4).

\section{Discussion}

This study assessed the knowledge, attitude and practice of environmental sanitation in semi-urban communities in a developing country. Though it was revealed that most of the respondents were aware of environmental sanitation mainly through the mass media which was similarly reported by Adogu et al., from a previous study [18], only about $23 \%, 39 \%$ and $21 \%$ of the respondents had a good level of environmental sanitation knowledge attitude and practice respectively.

In spite of the fact that, most of the respondents' self-assessment of their level of community sanitation was graded as moderate to good, their actual level of practice for a majority of the respondents was poor to moderate. As a result, 
Table 4. Environmental sanitation practices among respondents in semi-urban communities in Orlu.

Variable
${ }^{\star}$ Major types of solid waste generated $(\mathrm{n}=420)$
Estimated quantity of solid waste generated per household or business
premise per week $(\mathrm{n}=420)$
Mean waste generated $=14.1 \pm 0.94 \mathrm{~kg}$.
Average waste generated per person $/$ week $=2.69 \mathrm{~kg}$

Organic/perishables

Paper/cartons/glass

Plastic/polythene bags

Clothing/leather

Stationery

Electronic waste

Construction materials

1 - 2 buckets $(5-10 \mathrm{~kg})$

3 - 4 buckets $(11-20 \mathrm{~kg})$

5 - 10 buckets $(21-40 \mathrm{~kg})$

Can't estimate

Use of cover bins

Bags/sacs/nylon bags

Open dumping

Use of uncovered bins

Use of baskets

2 - 3 times per week

Once per week

Daily

Wheel barrows

Head pans

Private closed carriers

Dragging on the floor

Yes

No

Yes

No

Don't know

Open dumping

Burning

Composting

Recycling

Hog feeding

Sanitary land fill

Not sure

Yes

No

Yes

No

Don't know

Yes

No

Don't know
$314(74.8)$

$232(55.2)$

$165(39.3)$

$106(25.2)$

$64(15.2)$

$43(10.2)$

$25(6.0)$

$173(41.2)$

$127(30.2)$

$59(14.0)$

$61(14.5)$

$231(55.0)$

$169(40.2)$

$127(30.2)$

116 (27.6)

95 (22.6)

$202(48.1)$

$116(27.6)$

$102(24.3)$

166 (39.5)

144 (34.3)

$69(16.4)$

$41(9.8)$

$83(19.8)$

337 (80.2)

146 (34.8)

$207(49.3)$

67 (16.0)

209 (49.8)

61 (14.5)

$55(13.1)$

$23(5.5)$

$19(4.5)$

$5(1.2)$

48 (11.4)

$169(40.2)$

251 (59.8)

$213(50.7)$

$106(25.2)$

$101(24.0)$

$82(19.5)$

287 (68.3)

$51(12.1)$ 


\section{Continued}

\begin{tabular}{|c|c|c|}
\hline \multirow[t]{3}{*}{ If yes, how frequently? $(\mathrm{n}=82)$} & Yearly & $33(40.2)$ \\
\hline & Monthly & $31(37.8)$ \\
\hline & Weekly & $18(22.0)$ \\
\hline \multirow{3}{*}{$\begin{array}{l}\text { Does your community observe a monthly environmental sanitation day? } \\
(\mathrm{n}=420)\end{array}$} & Yes & $295(70.2)$ \\
\hline & No & $43(10.2)$ \\
\hline & Don't know & $82(19.5)$ \\
\hline \multirow{3}{*}{$\begin{array}{l}\text { Has monthly environmental sanitation day benefited the community? } \\
(\mathrm{n}=295)\end{array}$} & Yes & $149(50.5)$ \\
\hline & No & $83(28.1)$ \\
\hline & Don't know & $63(21.4)$ \\
\hline \multirow{3}{*}{$\begin{array}{l}\text { Are there any communal bush clearing and gutter cleaning activities? } \\
(\mathrm{n}=420)\end{array}$} & Yes & $187(44.5)$ \\
\hline & No & $107(25.5)$ \\
\hline & Don't know & $126(30.0)$ \\
\hline \multirow[t]{3}{*}{ How frequently is the bush clearing and gutter cleaning activities? $(\mathrm{n}=187)$} & Monthly & $146(78.1)$ \\
\hline & Weekly & $27(14.4)$ \\
\hline & Yearly & $14(7.5)$ \\
\hline
\end{tabular}

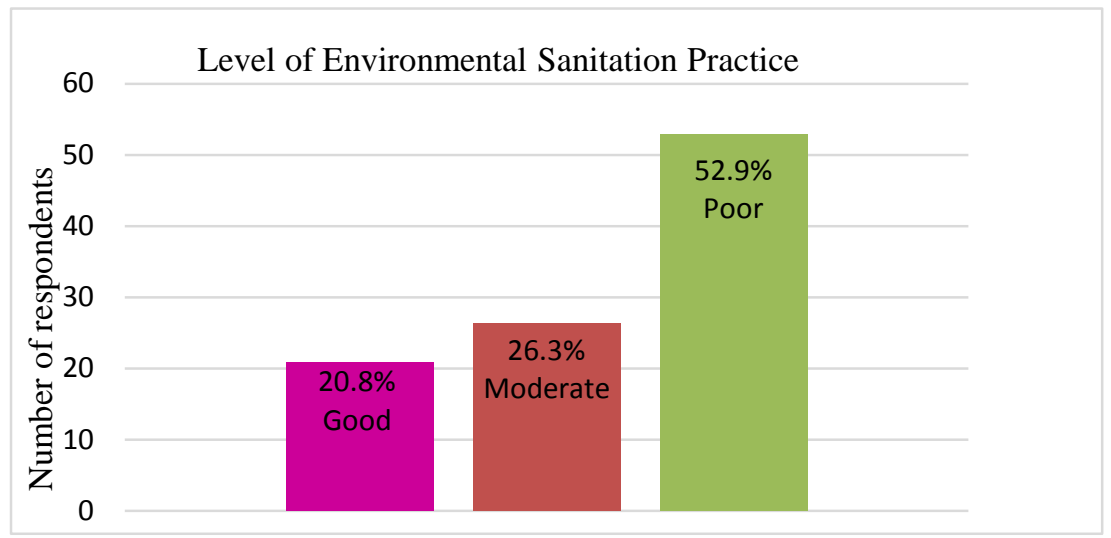

Figure 3. Overall level of environmental sanitation practice among respondents in semi-urban communities in Orlu.

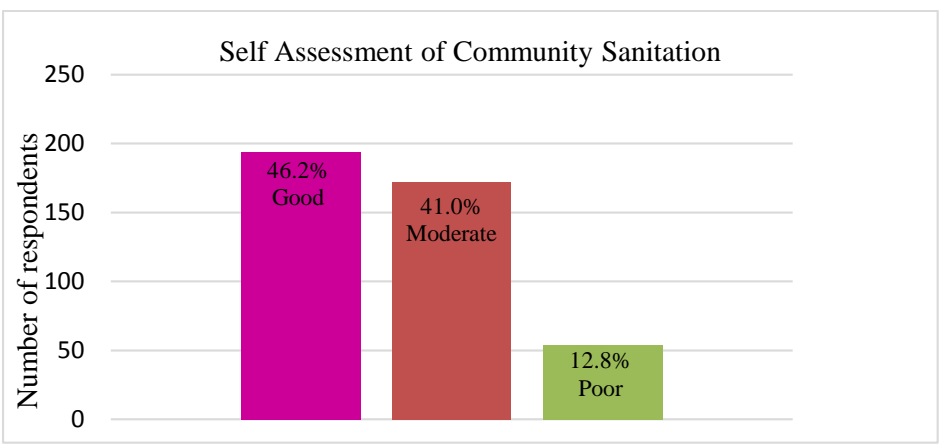

Figure 4. Self-assessment of community sanitation among respondents in Semi-urban communities in Orlu.

there seems to be a gap between their level of practice of sanitation and the perception of the level of sanitation they practice. In order words, they appear not to appreciate the inadequacy and inappropriateness of the environmental sanita- 
tion they actually practice. This may be attributed to the level of knowledge and attitude observed among the respondents in the present study. This level of knowledge and attitude observed could also be attributed to their level of education, as more than half of the respondents either had no education or had a primary level of education.

Previous studies have observed significant relationships between knowledge of sanitation and education, with higher levels of education being associated with better knowledge, as formal education provides the foundation for better understanding which invariably, improves the level of knowledge [19] [20] [21] [22]. Also, according to Agbola [23] and supported by George [24], it was suggested that attitude is a response that is learned and as such, can be influenced by education; so education, could therefore be a tool for changing or modifying the way people perceive events or actions. This was further highlighted in a study among Nigerian teachers [25], where it was reported that, most of the teachers had a positive attitude towards environmental issues which was a consequence of their level of education.

Even with the high level of environmental sanitation awareness observed in most of the respondents, it was still obvious that the depth of sanitation knowledge was lacking i.e. inadequate and inappropriate knowledge content. For example, where more than half of the respondents in the present study did not know that sewage disposal and more so, that the provision of safe water constitutes appropriate environmental sanitation; or where a majority of the respondents regarded open dumping as an appropriate waste disposal method or did not know that sanitary land fill and incineration as appropriate methods; or where up to one quarter to one third of the respondents either did not know that infections, unhealthy living conditions or blocked drainages were consequences of inappropriate environmental sanitation.

Similarly, their level of attitude also compounded the level of inadequacy and inappropriateness of their knowledge, where as high as $17 \%-30 \%$ of the respondents were either undecided or were of the opinion that solid waste could be thrown or sewage discharged into the streams; or that you could urinate and defecate near wells; or that solid waste could be spread around the compound to decay naturally into the soil; or that all waste bins need not have covers and could be kept without covers in the kitchen. This level of knowledge and attitude among the respondents in the present study was not similarly observed in other studies, where it was reported that, a majority of the respondents were knowledgeable; and or, had a positive attitude towards environmental sanitation [25] [26] [27].

The practice of environmental sanitation in the present study was poor to moderate in a majority of the respondents. This could have been influenced by their level of education, knowledge and attitude towards environmental sanitation; as it was observed in a study by Iwu et al., [28] among traders in Imo State, where it was reported that, the level of knowledge, attitude and education were significantly associated with waste management practice. Arora et al., [19] also 
suggested that, people with good knowledge that is usually associated with good practice, are more capable of properly managing waste. Furthermore, previous studies have reported the association of education, and or knowledge with the practice of environmental sanitation [17] [20] [21] [29]; and according to Olofsson et al. [30], the environment is more of a concern to people that are educated, who consequently act on preserving it.

The storage of waste using covered bins within the household or business premise environment was observed in a higher proportion of the respondents in the present study which was similarly observed in other studies done Owerri and Awka cities in Nigeria [18] [31]. Also, the practice of subsequently disposing these wastes by open dumping was the most common practice by about half of the respondents in the present study. This practice still appears to be prevalent in Nigeria, as was observed in previous Nigerian studies [18] [31] [32]. The practice of open dumping observed in the present study, is further compounded by the fact that three quarters of the respondents either did not know or did not have a designated central area for waste disposal and as such, probably dumped their waste indiscriminately.

So it appears that, even if the people are willing to practice proper sanitation, they are constrained by the lack of, or inadequacy of existing sanitation infrastructure including sanitation governance. This is further highlighted in the present study, where about half of the respondents either did not know of, or did not have a health sanitation committee; or where more than three quarters of the respondents either did not know of, or have visits by sanitary inspectors; or where more than half of the respondents either did not know of, or organize communal sanitation activities like bush clearing and gutter cleaning in their respective communities. Therefore, a demand led approach in sanitation that borders on behavioural change especially in our environment, cannot be fully effective unless adequate basic sanitation infrastructure is first established.

Finally, it was also observed that, the attitude towards waste segregation among the respondents in the present study was poor as more than three quarters of the respondents felt it unnecessary to separate waste before disposal. The lack of practice and appreciation for the need to separate waste before disposal seems to be a common trend especially in African countries [18] [28] [33] [34]. A study in Zambia, [35] reported that participation in solid waste separation depended on the level of awareness and educational status. Furthermore, Iwu et al., [28] was of the opinion that the people do not see the necessity and benefits to segregate their waste and this is probably due to the lack of appropriate education on its benefits, the perception that waste segregation is the sole responsibility of sanitation employees and the burden of the cost associated with purchasing and maintaining separate disposal receptacles.

\section{Conclusion}

This study established that the levels of sanitation knowledge, attitude and practice was poor to moderate; as a good level of knowledge and practice of envi- 
ronmental sanitation was only observed in less than one quarter of the respondents with just above one third of them having a good level of attitude and close to half having an erroneous perception that their level of environmental sanitation is good. A lot of attention is still required in the area of environmental sanitation especially in developing countries like Nigeria, with respect to not only employing and promoting strategies that influence behavioural change through effective regular education and awareness campaigns that are targeted, appropriate and consistent; but also, by advocating for increased public sector investments in basic sanitation infrastructures that is sustainable, well planned and coordinated. This will form the basis for adopting demand led approaches that will further empower people to improve their own sanitation.

\section{Acknowledgements}

We thank all the participants in this study and the research assistants who helped during the data collection.

\section{Authors' Contributions}

All the authors participated in the study.

\section{Competing Interest}

The authors hereby declare that there are no competing interests.

\section{Source of Funding}

There was no external source of funding.

\section{References}

[1] World Health Organization (WHO) (2017) Sanitation. http://www.who.int/topics/sanitation/en/

[2] World Health Organization (WHO) (2004) The Sanitation Challenge: Turning Commitment into Reality. http://www.who.int/water_sanitation_health/hygiene/sanchallengecomp.pdf

[3] Mara, D., Lane, J., Scott, B. and Trouba, D. (2010) Sanitation and Health. PLoS Med, 7, Article ID: e1000363. https://doi.org/10.1371/journal.pmed.1000363

[4] World Health Organization (WHO) (2017) Sanitation Fact Sheet. http://www.who.int/mediacentre/factsheets/fs392/en/

[5] Prüss-Üstün, A., Bos, R., Gore, F. and Bartram, J. (2008) Safer Water, Better Health: Costs, Benefits and Sustainability of Interventions to Protect and Promote Health. World Health Organization, Geneva.

[6] Merchant, A.T., Jones, C., Kiure, A., Kupka, R., Fitzmaurice, G., et al. (2003) Water and Sanitation Associated with Improved Child Growth. European Journal of Clinical Nutrition, 57, 1562-1568. https://doi.org/10.1038/sj.ejcn.1601725

[7] Genser, B., Strina, A., Teles, C.A., Prado, M.S. and Barreto, M.L. (2006) Risk Factors for Childhood Diarrhoea Incidence: Dynamic Analysis of a Longitudinal Study. Epidemiology, 17, 658-667. https://doi.org/10.1097/01.ede.0000239728.75215.86

[8] Schmidt, W.P., Cairncross, S., Barreto, M.L., Clasen, T. and Genser, B. (2009) Re- 
cent Diarrhoeal Illness and Risk of Lower Respiratory Infections in Children under the Age of 5 Years. International Journal of Epidemiology, 38, 766-772. https://doi.org/10.1093/ije/dyp159

[9] World Health Organization (WHO) (2017) Diarrhoeal Disease Fact Sheet. http://www.who.int/mediacentre/factsheets/fs330/en/

[10] Hotez, P.J., Molyneux, D.H., Fenwick, A., et al. (2007) Control of Neglected Tropical Diseases. The New England Journal of Medicine, 357, 1018-1027. https://doi.org/10.1056/NEJMra064142

[11] Daramola, O.P. (2012) Clapping with One Hand: The Case of Urban Environmental Sanitation Practices in Nigeria. Journal of Applied Technology in Environmental Sanitation, 2, 223-228.

[12] Bello, H. (2007) Environmental Sanitation Practices in the Core of Ikorodu, Lagos State. Dissertation to the Department of Urban and Regional Planning, Faculty of Environmental design and Management, Obafemi Awolowo University Ile Ife. https://www.scribd.com/doc/61919266/environmental-sanitation-practices-in-the-c ore-of-ikorodu-lagos-state-nigeria

[13] UNICEF (1999) A Manual on Hygiene Promotion UNICEF New York.

[14] Cairncross, S. and Valdmanis, V. (2006) Water Supply, Sanitation, and Hygiene Promotion. In: Jamison, D.T., Breman, J.G., Measham, A.R., et al., Eds., Disease Control Priorities in Developing Countries, 2nd Edition, Oxford University Press and World Bank, New York, 771-792.

[15] National Population Commission (NPC) Federal Republic of Nigeria 2006 Population and Housing Census; Priority Table III.

http://www.population.gov.ng/images/Vol\%2003\%20Table\%20DSx\%20LGAPop\%2 0by\%20SDistrict-PDF.pdf

[16] Cochran, W.G. (1963) Sampling Technique. 2nd Edition, John Wiley and Sons Inc., New York.

[17] Aswathy, S.K. (2015) Knowledge and Practice Regarding Environmental Sanitation and Hygiene among General Population: A Cross Sectional Survey. Global Journal for Research Analysis, 4, 158-159.

https://www.worldwidejournals.com/global-journal-for-research-analysis-GJRA/file .php?val=November_2015_1447852588_52.pdf

[18] Adogu, P.O.U., Uwakwe, K.A., Egenti, N.B., Okwuoha, A.P. and Nkwocha, I.B. (2015) Assessment of Waste Management Practices among Residents of Owerri Municipal Imo State Nigeria. Journal of Environmental Protection, 6, 446-456. https://doi.org/10.4236/jep.2015.65043

[19] Arora, L. and Agarwal, S. (2011) Knowledge, Attitude and Practices Regarding Waste Management in Selected Hostel Students of University of Rajasthan, Jaipur. International Journal of Chemical, Environmental and Pharmaceutical Research, 2, 40-43.

[20] Chengula, A., Lucas, B.K. and Mzula, A. (2015) Assessing the Awareness, Knowledge, Attitude and Practice of the Community towards Solid Waste Disposal and Identifying the Threats and Extent of Bacteria in the Solid Waste Disposal Sites in Morogoro Municipality in Tanzania. Journal of Biology, Agriculture and Healthcare, 5, 54-65.

[21] Jatau, A.A. (2013) Knowledge, Attitudes and Practices Associated with Waste Management in Jos South Metropolis, Plateau State. Mediterranean Journal of Social Sciences, 4, 119-127. https://doi.org/10.5901/mjss.2013.v4n5p119

[22] Samuel, E.S. (2006) Environmental Sanitation Knowledge among Primary School Pupils in Idemili North Local Government Area of Anambra State. Journal of En- 
vironmental Health, No. 3, 5-12.

[23] Agbola, T. (1993) Environmental Education in Nigerian Schools. In: Filho, W.L., Ed., Environmental Education in the Commonwealth, the Commonwealth of Learning, Vancouver.

[24] George, F. (2007) Problems of Solid Waste Management in Nima, Accra. Undergraduate Research Journal for the Human Sciences, 6, 26. http://www.kon.org/urc/v6/george.html

[25] Olawepo, J.A. and Jekayinfa, A.A. (1999) Assessment of the Environmental Attitudes and Practices of Teachers Undergoing Sandwich Degree Programmes in Nigeria. Nigerian Journal of Research and Development in Higher Education, 3, 1-17. https://studylib.net/doc/16120750/assessment-of-the-environmental-attitudes-andprogrammes

[26] Adeyemo, F., Oyadiran, G.O. and Afemikhe, J.A. (2013) Knowledge, Attitude and Practice on Waste Management of People Living in the University Area of Ogbomoso, Nigeria. International Journal of Environment, Ecology, Family and Urban Studies, 3, 51-56.

[27] Yadavannavar, M.C., Berad, B.A., Aditya, S. and Jagirdar, P.B. (2010) Biomedical Waste Management: A Study of Knowledge, Attitude, and Practices in a Tertiary Health Care Institution in Bijapur. Indian Journal of Community Medicine, 35, 170-171. https://doi.org/10.4103/0970-0218.62591

[28] Iwu, A.C., Duru, C.B., Uwakwe, K.A., Diwe, K.C., Merenu, I.A., Emerole, C.A., et al. (2016) Assessment of Waste Management Practices among Traders in Major Markets in Owerri, Imo State, Nigeria. International Journal of Health Sciences and Research, 6, 7-17.

[29] Daramola, O. and Olowoporoku, O. (2016) Environmental Sanitation Practices in Osogbo, Nigeria: An Assessment of Residents' Sprucing-Up of Their Living Environment. Economic and Environmental Studies, 16, 699-716.

[30] Olofsson, A. and Öhman, S. (2006) General Beliefs and Environmental Concern. Trans-Atlantic Comparisons. Environment and Behavior, 38, 768-790. https://doi.org/10.1177/0013916506287388

[31] Abejegah, C., Abah, S.O., Awunor, N.S., Duru, C.B., Eluromma, E., Aigbiremolen, A.O., et al. (2013) Market Sanitation: A Case Study of Oregbeni Market Benin City Edo State, Nigeria. International Journal of Basic, Applied and Innovative Research, 2, 25-31.

[32] Efe, S.I. (2013) Waste Disposal Problems and Management in Ughelli, Nigeria. Journal of Environmental Protection, 4, 4-11. https://doi.org/10.4236/jep.2013.44A002

[33] Modebe, I.A., Onyeonoro, U.U., Ezeama, N.N., Ogbuagu, C.N. and Agam, N.E. (2009) Public Health Implications of Household Solid Waste Management in Awka, South East, Nigeria. The Internet Journal of Public Health, 1, 1-6. http://ispub.com/IJPH/1/1/12848

[34] Yoada, R.M., Chirawurah, D. and Adongo, P.B. (2014) Domestic Waste Disposal Practice and Perceptions of Private Sector Waste Management in Urban Accra. BMC Public Health, 14, 697. https://doi.org/10.1186/1471-2458-14-697

[35] Banga, M. (2011) Household Knowledge, Attitudes and Practices in Solid Waste Segregation and Recycling: The Case of Urban Kampala. Zambia Social Science Journal, 2, 27-39. 